\title{
GENERAL
}

While excellent results have been attained in practical use of the Wright System of fire hazard measurement, it is believed that it would have a still wider application if it could be further simplified without sacrifice of accuracy. Every effort should be made to present all data for field use in the simplest possible form.

Consideration should be given by forest authorities to fuller uses which may be made of the system in order that the maximum savings may be effected through its use.

At Petawawa last season, experiments were conducted on the use of 20 per cent solution of calcium chloride in water for use with hand fire pumps in fighting grass fires. The sprayed guards remain wet until rain comes. It is recommended that further research be carried out, preferably in co-operation with the Research Council, on the use of inexpensive chemicals in fire suppression.

There is great need for special equipment and apparatus in fire hazard research. Owing to hitherto limited appropriations much of the equipment used has been of the most primitive nature and the degree of progress made in spite of this handicap is rather remarkable. The most pressing need at present is for some means of accurately measuring the intensity of test fires under varying conditions in order that they may be compared. It is recommended that this and other instrumental problems be referred to the Research Council for solution.

Finally your committee is of the opinion that excellent and valuable work is being done in Canada on forest fire research and that the fullest financial support should be accorded to those engaged in this work.

\section{Respectfully submitted,}

H. Метнот, Chairman

J. G. WRIGHT, Secretary

\section{REPORT ON THE SUB-COMMITTEE ON FOREST ENTOMOLOGY OF THE CANADIAN SOCIETY OF FOREST ENGINEERS}

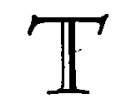

HE FINAL organization of the Sub-committee on Forest Entomology was deliberately delayed until some time after the conference on Forestry Research which was held at Ottawa in November. Rumours of the formation of a new Research Committee, under the auspices of the Research Council, were heard at the time of the summer meeting of the 
Society of Forest Engineers at Petawawa. From what could be learned at that time, it appeared that the two distinct committees might have the same general aims and it seemed likcly that there might result a certain amount of duplication of effort. However, after the close of the Research Conference, it was decided not to wait any longer and to proceed with the recruiting of the personnel of the Sub-committee.

At an early date during the summer, Mr. Georges Maheux, Provincial Entomologist, Quebec, had been approached concerning the office of Secretary of the Sub-committee and he then asked to be excused on the grounds that in his present position of Provincial Entomologist he no longer took any active part in Forest Entomology. To replace Mr. Maheux I took it upon myself to. find a new Secretary and requested Mr. G. A. Mulloy, of the Forest Service, Ottawa, to act in his stead. It secmed desirable to have some one in Ottawa to act in this capacity rather than a person located at some distant point where it would be difficult to make the necessary contacts. Mr. Mulloy kindly agreed to serve.

The other members of the Sub-committee were chosen with a view to. having representatives in all the principal centres of the Dominion, namely, the Maritime Provinces, Quebec, Ontario, the Prairie Provinces and British Columbia. In cach of these, one or more entomologists were asked to serve as central agents for the collection and distribution of information. The other memhers were chosen either from the Provincial Forest Serviccs or the Industrial organisations.

Both in the Maritimes and in British Columbia, representation is not as complete as it is in Quebec and Ontario. It is hoped that in the near future this. deficiency will be remedied and the entomologists acting in the two above named regions will be asked to secure the addition of some members from the Forest Services and from business concerns.

Complete plans for the operation of the committee have not been made as yet and much will depend upon a number of circumstances which it is impossible to foresee at present. For the time being, the principal object of the committee and the one to be immediately implemented is the organization of a forest insect survey in which all the members of the committee will be asked tor co-operate to the hest of their ability.

In the past, the Division of Forest Insects has maintained a Forest Intelligence Service, in co-operation with a number of other agencies in various parts of the Dominion. It is intended to develop this service and to find ways and means whereby its efficiency can be increased. It is hoped that during the coming year at least two or three additional special circulars, with coloured illustrations, will be made available for distribution annong foresters and forest 


\section{REPOR'T ON FOREST PATHOLOGY}

rangers and that these will be used in comnection with the survey, as a guide in making reports on the principal, known insects.

A mailing list containing the names of men most likely to be active in this connection will be made and the members of the committee will be asked to urge more active co-operation on the part of foresters and rangers in connection with the reporting of insect outbreaks. A special plea will be made to all concerned for the transmittal of information concerning insects not in outbreak and a system will be devised to facilitate the collection and transmittal of living specimens to be reared at various laboratories, the object being to secure essential information concerning the identity of insects, the connection of immature stages to adults, the effect of parasitic species in different regions, as well as the extent of their occurrence. Another activity of the committee will consist in the publication, twice yearly, of a mimeographed report concerning the activities of the committee and the forest insect situation in general. This will be distributed to all parties manifesting an interest in Forestry and Forest Entomology. Members of the committee will be asked to contribute to the circular.

Owing to the scattered nature of the membership it is not likely that it will ever be possible to have a meeting of all the members, but an effort will be made, whenever opportunity presents itself, to bring together as many members as possible and discuss matters relating to forest insects. From time to time, the members will be asked to submit suggestions, in writing, and to present any problems that may be peculiar to the region which they represent. By the latter method, some suggestions concerning points of general interest have already been received, among others:-

(1) The advisability of establishing an cntomological camp in connection with forest research projects conducted by the International Pulp and Paper Company in the Gatineau region.

(2) A general survey of forest insect damage in British Columbia, its present extent and its probabilities for the future.

(3) The occasional publication of bibliographies concerning the principal forest insects.

(4) A special investigation of methods of control to be used against LeConte's sawfly in Ontario, the forest tent caterpillar in the Prairies, and other similar pests.

(5) Improved methods for the sending of specinens in connection with reports.

All these matters will be taken up in the near future. In general, it may be said that the work of the committee is meeting with approval and that it is expected that it will be possible to report practical results within the coming year.

\section{J. J. DEGRYse, Chairınan, Sub-committee.}

